筫血の改善: 化学療法 (CDDP + 5FU, CDDP + ADM + CPMなど）中に原則として血中へモグロビン值が $10 \mathrm{~g} / \mathrm{dl}$ 末満になった症例を対象に EPOCH を週 3 回 静脈内投与した $(3000 \mathrm{U} \times 3$ または $6000 \mathrm{U} \times 3 /$ 週)。を の結果， $\mathrm{EPOCH}$ 投与によって筫血の改善傾向が認め られた．全例に副作用は観察されなかったが，造血に
際しては鉄利用が亢進するため血清鉄值が低下し，鉄 剤の補給が必要であった。

以上より頭頸部癌化学療法がひきおこす貧血の防止 に EPOCH 投与が有用かつ安全であることが判明し た.

\title{
253. 中耳真珠腫緊急手術施行例の術式の検討
}

\author{
赤池徽哉・大谷 跟・小川 洋（福島医大）
}

はじめに中耳真珠腫の中には数は少ないが, 頭蓋 内合併症などが疑われて堅急手術を必要とするものが ある。今回われわれは中耳真珠腫の緊急手術例の衍式 について検討を行い，若千の考察を加え報告した。

結果 1985年 1 月から1990年 6 月までに当科で手術 㟥行った中耳真珠腫新鮮例156耳のうち，10耳 $(6.4 \%)$ に緊急手術を行った。年齢は 3 歳から76歳までで平均 32.6 歳ですった。性別では男性 9 耳, 女性 1 耳と男性 记非常に多い傾向がみられた。緊急手術に至った理由 としては, 耳性頭蓋内合併症が疑われたものか, 西る いはその危険性が高いと判断されたものが 9 耳, 顔面 神経麻痺が 1 耳であった。緊急手術が必要と判断され たその日のうちに手術を行ったものは 5 耳で，2 日目 から6日目までに手術を行ったものは5耳であった。 初回手術の術式は真珠腫による破壃があまりにも高度 であったため，初回に中耳根本手術となった症例 1 を 除〈と, 残りの9耳はすべて初回に乳突削開術を行っ て排膿した後，抗生剂を十分投与して炎症をおさめ， 時期を放いて 2 回目の手術を施行した。 2 回目の手術 の術式は, 中耳根本手術が 1 耳, 保存的耳根が 4 耳, 鼓室形成術が 4 耳であった。 鼓室形成術例のうち外耳 道処理法別にみると closed method が 2 耳, open methodが 2 耳であった。また，一期的にI型としたも のが 1 耳, 段階的手術の○型としたものが 3 耳であつ
た. 後に 2 次手術で O型の 3 耳のうち 1 耳はIII型変法 に, 1 耳はIV型変法となった。

考察 今回の症例の最終的な術式をみると，20\%の 症例が中耳根本手術となったが, 一方で保存的耳根を $40 \%$ に，また鼓室形成術を $40 \%$ に行うことができた。

こ机をさらに即日入院・手術となったいわ省緊急 手術の症例 5 耳についてみた場合, 中耳根本手術は 40 $\%$ と倍になるものの, 保存的耳根を $20 \%$, 鼓室形成術 を $40 \%$ に行うことができた。このような結果から中耳 真珠腫の㛑急手術は排澧を目的として乳突削開術にと どめ, 強力な抗生剂の投与で局所および全身状態が改 善したところで, 聼力, 真珠腫の進展範国などから, その後の術式を検討することが大切である。そそうする ことによって比較的多くの症例で鼓室形成術が可能と なり，聴力を犠牲にした中耳根本手術を極力避けるこ とができるものと思われた。

質問 山崎恵之(福岡大)。1）乳突洞にてかなりの Eiter 流出を認めるが，抗生剂の投与はいかほどか.

2) また顔面神経麻猈があつた症例は術前の大コアは いかほどで，術後はどの位回復を認めたか。．応答 1) 症例に上り抗生剤の種類は異なるが，いずれも強 力な抗生剂投与を行った．2）初診時はほほ完全麻㿁 の状態であった。半年後の2 次手術時には正常に回復 した.

\section{4。顔面神経麻痖合併真珠腫における術式の検討}

\section{渡辺徳武・吉村弘之・箫田三徳・茂木五郎（大分医大）}

目的真珠腫性中耳炎の合併症として顔面神経麻渒 は必ずしも少なくなく，麻㽻の発生機序から速やかな 真珠腫病変心除去々顔面神経減荷必要とする。しか し, 解剖学的複雑さや真珠腫摘出に伴亏神経障害の危 険性などのためその手術治療は困難で, 術後も再感染 や㽷着などにより麻痺再発を来す恐れがあり，顔面神 経麻痺合併真珠腫症例に打ける手術術式について検討 した。

対象 顔面神経麻㿎を合併し手術治療を施行した真 珠腫性中耳炎は 6 症例で，これら症例の平均年齔は64
歳（55〜72歳）と高齢者であった。手術直前に麻俥存 在が明らかにさ扎た不全麻䡒の 2 例を除き，4例は完 全麻痒で, 発症加ら7〜19日に手術治療を施行した。 真珠腫は，5例（83\%）では弛緩部を中心とした上鼓 室型で，1例 $(17 \%)$ では後象限型であった。上鼓室 型の 5 例中 3 例で外耳道保存型， 2 例では外耳道開放 型手術後に外耳道を骨膜骨弁にて再建し, 後象限型の 1 例では外耳道開放型手術を行った。水平部から垂直 部にわたり広沉に神経が露出されていた1例を除き全 例で砧骨除去後に水平部から垂直部にわたる神経滅荷 